devoted to the application of genetics to the improvement of the crop, methods of selection, and agricultural aspects and prospects in India. A very large section of the monograph is devoted to the genetics of rice, the inheritance of pigmentation, morphological, physiological and quantitative characters, correlations, linkage, mutations and cytology, each receiving detailed treatment. The factor of quality, as befits its importance, is discussed in its several aspects. The central aim of all this work is, of course, to improve rice production in a region where it is virtually the staple food. Here the authors make comparisons with rice production in other largeproducing countries, especially those in which high yields are obtained, and conclude that much can be achieved in India by the appropriate use of fertilizers. "That India has not been able to increase her production substantially is certainly not due to lack of experimental research or scientific knowledge. The most significant reason appears to be the wide gap between research and extension. The cultivator does appreciate the value of scientific knowledge but still he cannot make use of it." The monograph is well illustrated, with some good coloured plates.

\section{Seismology in New Zealand during 1951-53}

THE readings of seismograms obtained at thirteen New Zealand observatories (including Suva, Fiji) for the periods January-March and April-June 1951 have been published for the Geophysics Division of the New Zealand Department of Scientific and Industrial Research (pp. 16 and 13, respectively. Wellington: Government Printer, 1953). Earthquake epicentres follow a familiar pattern, as they also do for 1952. In the publication dealing with "Earthquake Origins in New Zealand during 1952" (Seism. Obs. Bull., $S-98$; pp. $4+1$ map. Wellington : Government Printer, 1953) it is stated that most of the epicentres in 1952 lay between latitudes $37^{\circ}$ and $43^{\circ} \mathrm{S}$, and there were no epicentres north-west of Karapiro. Isoseismal lines are given for the earthquake of August 28, 1952, with epicentre near Havelock North (greatest intensity, $6+$ ). The provisional seismological bulletins for July and August 1953 show that the greatest local earthquakes, on July 4 and August 1, both had instrumental magnitude $5 \cdot 3$. The former affected central and western parts of North Island (Tokaanu region), and the latter had an epicentre near lat. $44 \cdot 8^{\circ} \mathrm{S}$., long. $175 \cdot 8^{\circ} \mathrm{W}$

\section{Museum of Applied Arts and Sciences, Sydney: Report for 1953}

THE annual report for 1953 of the Museum of Applied Arts and Sciences, Sydney (pp. 14 ; published by the Museum, 1954), records the activities of this well-known institution under the energetic directorship of Mr. A. R. Penfold. Although the display side of the Museum is by no means neglectedsuch exhibits as one demonstrating the energy released by an atomic blast and another of a working compound condensing engine and boiler under steam bear ample witness to this-an impressive amount of scientific work has been accomplished. Such subjects as the establishment of plantations of commercially valuable eucalypts and tea trees in Australia, the effect of modern synthetic fibres on the Australian wool industry, and technical advice concerning paints and varnishes are an indication of the practical use to the nation of the resources of this Museum.

\section{Swedish Physics Conference of September 1952}

The sixth general physics conference of the Swedish National Committee for Physies was held in Stockholm during September 25-27, 1952. As it took place at the same time as the international instruments and measurements conference and exhibition, those attending the physics conference were able to participate in the sessions of the instruments conference, and members of the instruments conference in two of the sessions of the physics conference. The guest lecturers were Prof. E. Bak and Mr. J. R. Anderson, who spoke on microwave spectroscopy and special microwave measurements; Prof. E. Laurila on measuring instruments employing feedback; and Prof. S. Westin on a new electric calculating machine and on geotechnical measurements with strain gauges. The secretary of the physics conference was Dr. Sven Benner, of the Radiophysics Laboratory at the King Gustav V Jubilee Clinic, Gothenburg. Short summaries of the other papers presented to the conference are printed in the January number of Arkiv för Fysik (7, 73; 1954).

\section{Survey of Field Theory: Physical Society Meeting} in Birmingham

The autuman meeting of the Physical Society will be held in the Poynting Physics Building, University of Birmingham, during December 13-14, the subject being "A Survey of Field Theory". The meeting, which is being organized by Prof. R. E. Peierls, will consist of series of lectures on the interactions between mesons, nucleons, photons and electrons, and, since no specialist knowledge will be assumed, it is hoped that they will be suitable for experimentalists with a general knowledge of quantum mechanics and for theoreticians who do not specialize in field theory. Prof. Peierls will both give an introduction to the proceedings and sum up at the end. The papers will be as follows : fields and particles, by Dr. P. T. Matthews (Birminghama); interactions between fields, by Dr. A. Salam (Cambridge); the state of knowledge of the properties of $\pi$-mesons, by Dr. P. T. Matthews (Birmingham); and phenomena involving mesons and nucleons at high energy, by Dr. G. Feldman (Birmingham). Those who are not members of the Physical Society may attend, on completing an application form obtainable from the Physical Society, 1 Lowther Gardens, Prince Consort Road, London, S.W.7.

\section{University of Leeds}

Trre following appointments have been made in the University of Leeds : A. Richardson, lecturer in the Department of Electrical Engineering; Dr. J. H. Robertson, Brotherton lecturer in the Department of Inorganic and Structural Chemistry; Dr. P. Feltham and Dr. R. Shuttleworth, lecturers in metallurgy in the Department of Coal Gas and Fuel Industries with Metallurgy and Chemical Engineering; D. Payne, lecturer in agricultural chemistry ; and Dr. D. Dowson, lecturer in the Department of Mechanical Engineering. The title of emeritus professor has been conferred on Prof. J. W. Harvey, on his retirement from the chair of philosophy, and on Prof. A. N. Shimmin, on his retirement from the chair of social studies. Recent gifts to the University include the following : $£ 3,900$ over three years to the Department of Botany from the Nuffield Foundation for research under the direction of Prof. R. D. Preston on the molecular structure of the cell walls of plants ; $£ 1,000$ a year for two years to the 